Rundzellen vorhanden waren, die jedoch nach dem 1. Versuchstag nicht mehr nachweisbar waren. Ein Vergleich mit dem Verlauf des Markierungsindex im Granulationsgewebe der Leber ${ }^{2}$ hat gezeigt, dass es in der Milz innerhalb der ersten $24 \mathrm{~h}$ zu einem rascheren Anstieg und nach dem 2. Versuchstag zu einem schnelleren Abfall der Prozentsätze radioaktiv markierter Fibroblasten gekommen war. Die proliferative Aktivität nach dem 10 . Versuchstag war entsprechend der narbigen Heilungstendenz in der Milz sehr gering.

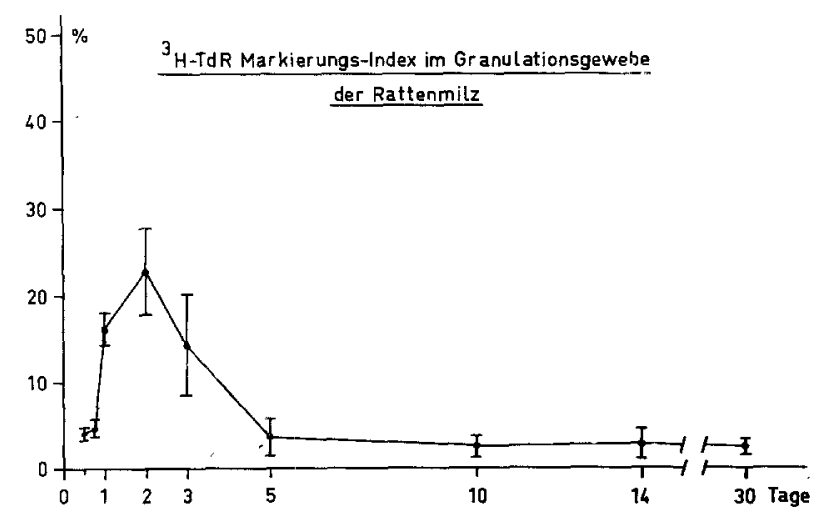

Fig. 2. Verlauf des ${ }^{3} \mathrm{H}$-Markierungsindex im Granulationsgewebe der Rattenmilz nach Kryonekrose in Abhängigkeit von der p.op. Versuchszeit.
Ebenso wie an den bislang untersuchten parenchymatösen Organen führt eine lokale Gewebsvereisung an der Milz zu einer irreversiblen Zellschädigung. Diese Kryonekrose heilt auch in der Milz sehr rasch narbig aus. Der Wundheilungsablauf unterstreicht somit, dass dieses schonende operative Verfahren ${ }^{4}$ auch an der Milz möglich ist.

Summary. The autoradiographic studies on spleen of rats show - compared with results after cryosurgery on liver and kidney of rats - that local deep tissue freezing induces irreversible cell injuries, but the localized spleen freezing is followed by an exceptionally fast healing process. After 3 weeks, there are no proliferative mesenchymal activities in the granulation tissue. 4 weeks after cryonecrosis, only a small scar can be detected on the spleen surface.

B. Helpap, K. Yamashita, H. Breining und S. LYMBEROPOULOS ${ }^{5}$

Pathologisches Institut dev Universität, Postfach, D-53 Bonn 1 (Deutschland), und Abteilungen für Pathologie und Urologie der RWTH in Aachen, Aachen (Deutschland), 15. August 1973.

4 S. LxMBeropoulos, Habil.-Schrift, Aachen 1970).

5 Mit Unterstützung des Landesamtes für Forschung NordrheinWestfalen in Düsseldorf.

\title{
Regeneration from Short Stumps of the Rat Gastrocnemius Muscle ${ }^{1}$
}

In some species of vertebrates, such as the chicken ${ }^{2}$, considerable regenerative outgrowth occurs from the cut surface end of a muscle stump, often to the extent that the original gross contours of the muscle are almost totally restored. Other species, for example the frog, are able to muster only a weak local regenerative response at the cut surface of a muscle stump, and grossly the size and shape of the muscle stump change but little ${ }^{3}$. LITVER et al. ${ }^{4}$, working on several limb muscles in the rat, reported that in $52-77 \%$ of the cases obvious elongation of the muscle stumps occurred and that often surprisingly normal appearing muscles developed. A major unresolved question in this work was why 'organic' regeneration of muscles from the stump occurred in many cases, but not in others. After 3 repetitions of the experiment of LITVER et al. ${ }^{4}$ on the gastrocnemius muscle of the rat, the answer to this question became apparent.

Methods. In 22 cases all of the gastrocnemius and plantaris muscles except for a $3-5 \mathrm{~mm}$ proximal stump was excised in $60-100 \mathrm{~g}$ male Wistar rats. During the operation, the rats were anesthetized with sodium pentobarbital. The biceps femoris muscle and the skin were sutured over the nearly empty bed of the muscle. The muscles were examined grossly at periods of 36-55 days after the initial excision operation.

Results. In 13 cases $(61.8 \%)$ considerable elongation of the muscle stump had occurred. The final lengths of the regenerated muscles ranged from $10-26 \mathrm{~mm}$. The 9 remaining muscle stumps $(38.2 \%)$ demonstrated either minimal elongation $(<2 \mathrm{~mm})$ or slight regression in length.

Elongation of the muscle stump was correlated with the successful regeneration of a functional Achilles tendon whereas non-elongation was normally associated with unsuccessful regeneration of the Achilles tendon. In all 13 cases of elongation the Achilles tendon had regenerated proximad and had re-established a good connection with the distal part of the muscle stump. It was sometimes necessary for the regenerating tendon to bridge a gap of $20-30 \mathrm{~mm}$ in order to make contact with the muscle. Although the mass of functional muscle tissue in these regenerates was always considerably less than normal, nevertheless the degree of restoration of normal form in these regenerates was often remarkable (Figure 1).

Seven of the 9 non-elongating muscle stumps were bound down to the underlying connective tissue, and their size and appearance was little changed from that at the original operation (Figure 2). In these cases the regenerating Achilles tendon had not extended as far as the muscle stump but had, itself, become attached to the underlying tissues. Two non-elongating muscle stumps were directly attached to regenerated tendons. Presently, no definitive explanation can be offered for their regenerative quiescence.

1 Supported by a grant from the Muscular Dystrophy Association of America.

2 A. N. STuditsky, Trudy Inst. Morphol. Zhivotnikh im A.N. Severtsov 11, 225 (1954).

3 B. M. CarLson, The Regeneration of Minced Muscles (S. Karger, Basel 1972).

4 G. M. Litver, N. N. Dampel, I. B. Simelson and V. B. Kostkin, Byull. exp. Biol. Med. 52, 101 (1961). 


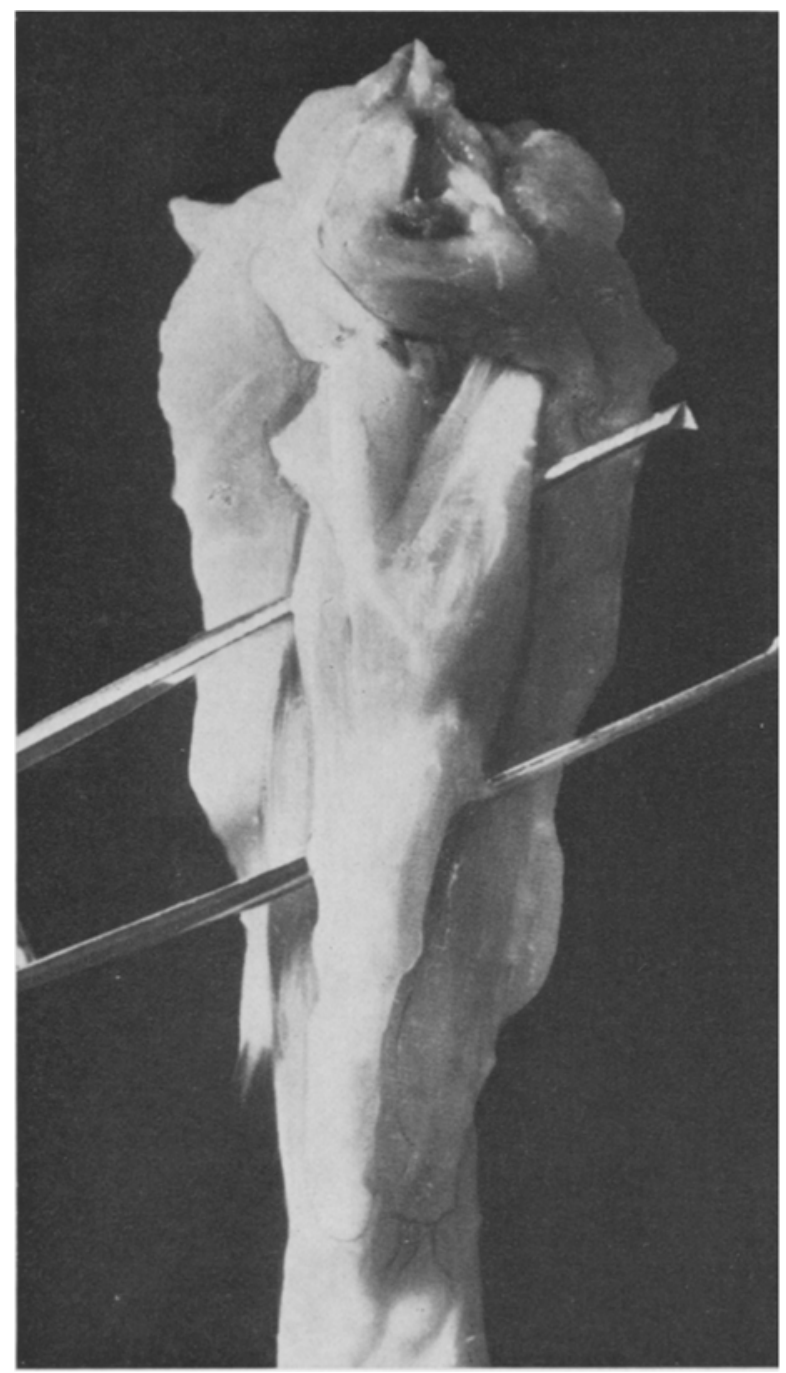

Fig. 1. Fifty five-day gastrocnemius regenerate which had arisen from 3-4 mm proximal stumps. The muscular part of this regenerate is $14 \mathrm{~mm}$ long. The distal $2 / 3$ of the regenerate is composed of connective tissue.

Discussion. This experiment demonstrates the importance of functional tendon connections as a determining factor in the success or failure of attempts to manipulate regenerating skeletal muscle. The necessity of tension or tendon connections for the elongation of regenerating minced muscles has been demonstrated by RUMYANTSEVA ${ }^{5}$ and by CARLSON ${ }^{3,6}$. Why elongation of the muscle stump failed to occur in two regenerates which had made connections with the new Achilles tendon is unclear unless the regenerated tendons were so bound down by adhesions that they could not exert effective tensile forces.

The overall form of elongating stump regenerates was remarkably similar to that of the normal gastrocnemjus muscle. Because of the good restoration of form, this type of regeneration has been called organ regeneration, and some authors ${ }^{4,7}$ have made a distinction between it and the tissue regeneration of muscle. Histologically there is no difference between the regeneration of mildly injured muscle and that in elongating stumps of entire muscle, and to this author the putative differences appear to be more a matter of degree than of kind.

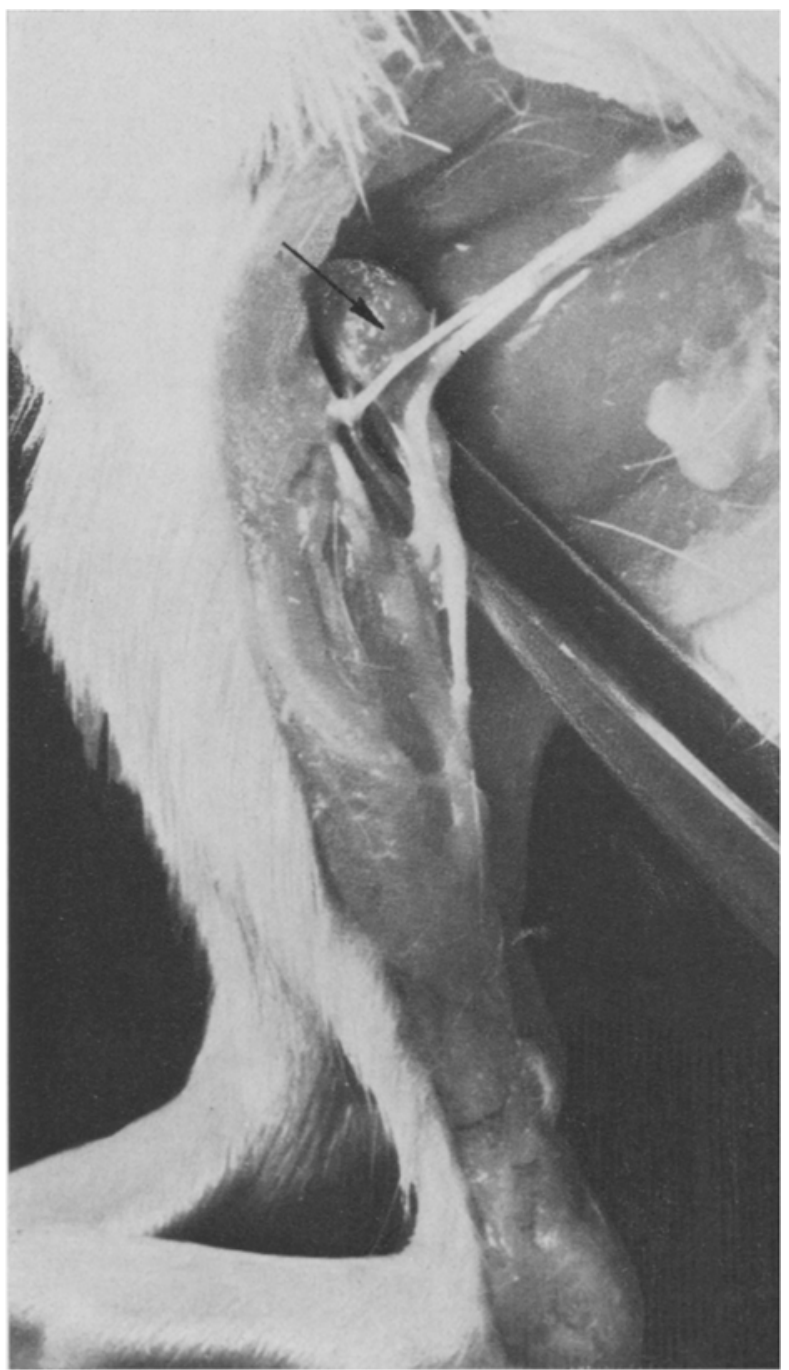

Fig. 2. Fifty five-day gastrocnemius regenerate which had arisen from 3-4 mm proximal stumps. In this case connections were not established with the stump of the Achilles tendon and the proximal stump (arrow) has increased to a length of 5-6 $\mathrm{mm}$ and was bound down to the underlying tissues.

Zusammenfassung. Nachweis der Regeneration eines neuen Muskels nach Entfernung des ganzen Gastrocnemius-Muskels der Ratte bis auf einen 3-4 $\mathrm{mm}$ langen Stumpf. Nur bei vorhandener Verbindung zwischen der regenerierenden Achilles-Sehne und dem proximalen Muskelstumpf kommt es zu bedeutender Verlängerung des proximalen Rests des Muskels.

\section{B. M. CARISON}

University of Michigan Medical School, Department of Anatomy, Amn Arbor (Michigan 48104, USA),

30 August 1973

5 O. N. Rumyantseva, Dokl. Akad. Nauk SSSR 125, 435 (1959).

6 B. M. CarLson, in Research in Muscle Development and the Muscle Spindle (Eds. Banker, Przybylski, VAN der Mevlen and VicTOR; Excerpta Medica, Amsterdam 1972), p. 3.

7 L. D. LIOSNER, Changes of Tissues and Regeneration of Organs (Izdatel. Znanie, Moscow 1970), in. Russian, 